\title{
MADNESS OF MAIN CHARACTER, DAVID IN DAVE PELZER'S TRILOGY : $A$ CHILD CALLED IT, THE LOST BOY, AND A MAN NAMED DAVE
}

\author{
Yolanda Mega Sari ${ }^{1}$, Dewi Purnama Sari \\ mariayolandams@gmail.com¹, dewi.purnama@binadarma.ac.id²
}

Universitas Bina Darma ${ }^{1}$, Universitas Bina Darma ${ }^{2}$

\begin{abstract}
Abstrak
Tesis ini berjudul kegilaan sang tokoh utama, David dalam trilogi Dave Pelzer: A Child Called It, The Lost Boy, dan A Man Named Dave. Dalam tesis ini, peneliti ingin mengetahui indikator-indikator kegilaan yang dialami David dan efek kegilaan dari karakter David kepada dirinya sendiri dalam trilogi A Child Called It, The Lost Boy, dan A Man Named Dave. Data dikumpulkan dari trilogi A Child Called It, The Lost Boy, dan A Man Named oleh Dave Pelzer. Kemudian, data penelitian ini dianalisis berdasarkan teori kegilaan oleh Michel Foucault. Data telah diambil dari beberapa kalimat dan paragraf dari trilogi. Jenis penelitian yang digunakan adalah metode deskriptif kualitatif. Hasil penelitian ini menunjukkan bahwa ada tiga indikator kegilaan yang dialami David didalam trilogi, yaitu keberadaan elite, asylum dan hukuman. Hukuman mental dan fisik adalah efek kegilaan dari karakter David kepada dirinya sendiri didalam trilogi.
\end{abstract}

Kata kunci: kegilaan, novel trilogi dave pelzer.

\section{Abstract}

This paper was aimed to find out the indicators of madness experienced by David and the effects of madness in David's character through himself in A Child Called It, The Lost Boy, and A Man Named Dave trilogy. The data was collected from A Child Called It. The Lost Boy, and A Man Named Dave trilogy by Dave Pelzer. Then, The data of this study were analyzed based on madness theory by Michel Foucault. The data had been taken from some sentences and paragraphs from the trilogy. The study design was the descriptive qualitative method. The results of this study indicated that there were three indicators of madness experienced by David through the trilogy, which were the existence of the elite, asylum and punishment. Mental and physical punishments were the effects of madness in David's character through himself in the trilogy.

Keywords: dave pelzer's trilogy, madness.

\section{INTRODUCTION}

Psychology and literature are two different aspects of knowledge that have various interrelationships. Psychology and literature study literature by looking at it as a psychological activity from both the author and the readers. According to Jatman (1985:165), psychology and literature have the same object, human and what differs between them is only in the space. He states that the object in the literary works are mentality, humanity and behaviorism that appear in the text as the imaginative world. But, for psychology, the objects are shown in the real world. Literary works, especially those in the form of prose such as short stories, dramas and novels must always show the story of the characters in living their lives. In writing literary work, the author must present a unique character with certain behavior to add the attraction of the story. This aspect is raised by literary

94 | Jurnal Kredo

Vol. 3 No. 1 Oktober 2019 psychology as a study material, especially regarding the background of the actions and thoughts of the characters related in literary works. By analyzing the psychiatric conditions of the characters in the literary work produced, it can be concluded how the psychological condition of the author when writing literary work. Madness is a kind of psychoanalysis since it also discusses about problems about the human environment, like phenomenon formed by elite group in a society.

Madness is a theory developed by a French historian and philosopher, PaulMichel Foucault or better known as Michel Foucault. Foucault is best known for his keen research in the fields of social institutions, especially psychiatry, medicine, as well as the humanities and prison systems, and his works on the history of sexuality. He was born in 1926 and died in 1984. The most prominent 
work of Foucault's thought is his first major work, The History of Madness (1961). Madness, according to Michel Foucault, is a phenomenon formed by elite groups in a society (Foucault 2002:337). This elite group uses the "madness" category as a weapon to get rid of parties that they do not want. When someone is said to be "mad" then he will be removed from the general public (Rosidi 2013). Finally, the composition of a society is governed by this elite group. This elite group creates certain symbols for crazy and sane classifications. The symbols are arranged in such a way that they become something scientific and generally recognized. So, elite is someone or a party that has a power. Mad and normal category were made from the elite.

In Foucault's madness theory, he also explains about asylum. Mad or unwanted people would be put in the asylum, even if it is innocent outside of it. For along time to come, and until our own day at least, it is imprisoned in a moral world (Foucault 1965:269). According to Foucault, asylum is a place used to regulate human behavior, which is another language from a place to separate people who are considered normal and abnormal or eccentric and unwanted by the elite, that place can be a mental hospital, prison, social institutions or any place that has the purpose to regulate the behavior of a person who is considered crazy or deviant in order to return to normal or in accordance with the law that applies by the elite.

The existence of punishment carried out for parties who are deemed to have deviant behavior until they can act rationally (in accordance with the wishes of the elite). According to Foucault (1975), as cited by Martono (2014:79-80), the punishment system that prevailed before the 19th century had characteristics: prioritizing sadistic physical punishment rather than psychological punishment and being carried out openly in public. The existence of the practice of punishment aimed to show the power of the authorities at that time and provide a deterrent "terrible" effect for the community at that time. The discipline in Foucault's thinking is a careful mechanism of control of the body. Discipline is a way of power to control individuals and ultimately produce obedient and useful individuals. The body is the main target of discipline.

Foucault also states that only the use of punishment distinguished, intreating the mad, the medications of the body from those of the soul or mentally. A purely psychological medicine was made possible only when madness was alienated in guilt (1965:182). In other words, by this guilt the madman became an object of judgement and punishment, and also punishment can be physically or mentally.

In short, there are three indicators of madness as stated by Foucault, which were the elite, asylum, and punishment.

The researcher chose trilogy of David Pelzer's novels titled A Child Called It, The Lost Boy, and A Man Named Dave to be analyzed by using the theory of Michel Foucault about madness. A Child Called It, The Lost Boy, and A Man Named Dave trilogy were interesting to discuss in terms of psychoanalysis theory of madness because the trilogy was based on the author's true life story about his past lives where David Pelzer's in his childhood, was tortured by his mother and shunned by those around him. A Child Called It, The Lost Boy, and A Man Named Dave trilogy were also enticing to analyze because David was said to be "crazy" then people around him tried to ostracize him from the society. The psychological aspects displayed in these novels were very closely related to human problems. On the basis of these assumptions, this study focused on the main character of the trilogy A Child Called It, The Lost Boy, and A Man Named Dave named David using the approach of Michel Foucault's psychoanalysis madness theory. This study analyzed the indicators of madness experienced by David and the effects of 
madness in David's character through himself in the trilogy. The literary analyses were narrowed by two focus points according to the purpose of the analyses and their ability to show how indicators of madness experienced by David and the effects of madness in David character through himself in the trilogy were expressed in the text.

Based on the explanations above, the researcher conducted a research entitled "Madness of Main Character, David in Dave Pelzer's Trilogy : A Child Called It, The Lost Boy, and A Man Named Dave". This study intended to find out the indicators of madness experienced by David Pelzer and also to find out the effects of madness in David's character through himself in A Child Called It, The Lost Boy, and A Man Named Dave trilogy. The results of this study was intended to understand more about the theory of madness by Foucault and madness of main character, David in the trilogy.

\section{METHODOLOGY}

The research design used qualitative method. According to Nazir (1988:63), qualitative descriptive method is a method in examining the status of a group of humans, an object, a set of conditions, a system of thought or a class of events in the present. The purpose of this study was to make a description, or painting systematically, factually and accurately of the facts, characteristics and relationships between phenomena investigated. The researcher focused on the main character of $A$ Child Called It, The Lost Boy, and A Man Named Dave trilogy, David. This study concerned with the deep analysis of David as the object of this study. The purposes of this study were to show the indicators of madness presented in literature and the connection between David's point of view and madness theory from the primary text and interpretations discussion of point of view which depicted indicators of madness experienced by David as the main character of A Child Called It, The Lost Boy, and A Man Named Dave trilogy. The result of this study was to present the data in writing form and also to give the explication of the object descriptively.

This study object was the point of view of the main character of $A$ Child Called It, The Lost Boy, and A Man Named Dave trilogy, David. The researcher used his point of view in analyzing the relationship between events in the story and the theory of madness by Foucault.

There were two techniques that used by the researcher for collecting the data. First, the researcher read the entire of David Pelzer's A Child Called It, The Lost Boy, and A Man Named Dave trilogy repeatedly. Second, the researcher took notes all of the data and matters related to madness theory by Foucault in A Child Called It, The Lost Boy, and A Man Named Dave trilogy.

There were some techniques for analyzing the data that used by the researcher of this study. First, the researcher identified the data that related to the problems of this research. Next, the researcher classified the data that has been taken. In the last technique, the researcher analyzed the data in accordance with the problems in the study.

\section{DISCUSSION}

The researcher found the indicators of madness that experienced by David Pelzer as the main character of $A$ Child Called It, The Lost Boy, and A Man Named Dave trilogy, which were the existence of elite, asylum, and punishment. There were some effects of madness in David's character through himself in the trilogy. They were the physical and mental punishments. 
3.1. Indicators of Madness

Experienced by David in $A$ Child Called It, The Lost Boy, and A Man Named Dave Trilogy

There were three indicators of madness as stated by Foucault, such as elite, asylum and punishment. The three indicators of madness on the trilogy can be seen in the each table below, from elite, asylum to punishment.

\subsubsection{Elite in A Child Called It, The \\ Lost Boy, and A Man Named Dave Trilogy}

In this part, the researcher explained about elite in A Child Called It, The Lost Boy, and A Man Named Dave trilogy, as can be seen from the table below.

\begin{tabular}{|c|l|l|}
\hline \multirow{2}{*}{ No. } & \multicolumn{2}{|c|}{ A Child Called It } \\
\cline { 2 - 3 } & \multicolumn{1}{|c|}{ Elite } & Chapter, Page, Paragraph \\
\hline 1. & David's mother & Ch.3, P.22, Par.2 \\
\hline 2. & David's classmates & Ch.4, P.30, Par.4 \\
\hline 3. & Russel & Ch.5, P.51, Par.4 \\
\hline 4. & David's father & Ch.5, P.54, Par.3 \\
\hline
\end{tabular}

Table 1. Elite Characters in A Child Called

\begin{tabular}{|c|c|c|}
\hline \multirow{2}{*}{ No. } & \multicolumn{2}{|r|}{ The Lost Boy } \\
\hline & Elite & Chapter, Page, Paragraph \\
\hline 1. & David's mother & Ch.1, P.7, Par.5 \\
\hline 2. & David's father & Ch.1, P.25, Par.1 \\
\hline 3. & Mark & Ch.1, P.17, Par.6 \\
\hline 4. & The policeman & Ch.1, P.19, Par.9 \\
\hline 5. & Ms Gold & Ch.2, P.38, Par.2 \\
\hline 6. & Mrs Catanze & Ch.4, P.55, Par.3 \\
\hline 7. & Lilian & Ch.4, P.52, Par.5 \\
\hline 8. & Larry $\mathrm{Jr}$ & Ch.4, P.60, Par.2 \\
\hline 9. & The psychiatrist & Ch.5, P.77, Par.4-5 \\
\hline 10. & Rudy & Ch.6, P.97, Par.4 \\
\hline 11. & John & Ch.6, P.105, Par.3 \\
\hline 12. & Gordon & Ch.7, P.128, Par.4 \\
\hline 13. & Russel & Ch.8, P.146, Par.1 \\
\hline 14. & Carlos & Ch.8, P.148, Par.5 \\
\hline 15. & Bobby & Ch.8, P.152, Par.6 \\
\hline
\end{tabular}

Table 2. Elite Characters in The Lost Boy

\begin{tabular}{|c|c|c|}
\hline \multirow{2}{*}{ No. } & \multicolumn{2}{|c|}{ A Man Named Dave } \\
\hline & Elite & Chapter, Page, Paragraph \\
\hline 1. & David's mother & Ch.1, P.12, Par.5 \\
\hline 2. & The nurse & Ch.1, P.24, Par.7 \\
\hline 3. & The master sergeant & Ch.3, P.46, Par.3 \\
\hline 4. & The sergeant & Ch.3, P.50, Par.5 \\
\hline 5. & The counselor & Ch.3, P.50, Par.7 \\
\hline 6. & $\begin{array}{l}\text { David's } \\
\text { grandmother }\end{array}$ & Ch.5, P.89, Par.1 \\
\hline 7. & David & Ch.9, P.177, Par.5 \\
\hline 8. & Patsy & Ch.11, P.206, Par.1 \\
\hline
\end{tabular}

Table 3. Elite Characters in A Man Named

\section{Dave}

From the table above, it can be seen that the most elite was in David's second novel titled The Lost Boy, the second was A Man Named Dave and the third was $A$ Child Called It. The most elite that David met was in his second book because he moved from one foster home to another, so he met more new people the most in The Lost Boy.

\subsubsection{Asylum in A Child Called It, The Lost Boy, and A Man Named Dave Trilogy}

In this part, the researcher explained about asylum in A Child Called It, The Lost Boy, and A Man Named Dave trilogy, as can be seen from the table below.

\begin{tabular}{|c|l|l|}
\hline \multirow{2}{*}{ No. } & \multicolumn{2}{|c|}{ A Child Called It } \\
\cline { 2 - 3 } & \multicolumn{1}{|c|}{ Asylum } & Chapter, Page, Paragraph \\
\hline 1. & $\begin{array}{l}\text { The administration } \\
\text { office }\end{array}$ & Ch.1, P.10 -11, Par.4 \\
\hline 2. & The corner treatment & Ch.3, P.21, Par.4 \\
\hline 3. & The garage & Ch.3, P.25, Par.1 \\
\hline 4. & The basement & Ch.4, P.30, Par.1 \\
\hline 5. & $\begin{array}{l}\text { Under the breakfast } \\
\text { table }\end{array}$ & Ch.4, P.42, Par.2 \\
\hline
\end{tabular}

Table 1. Asylum in A Child Called It

\begin{tabular}{|c|l|l|}
\hline \multirow{2}{*}{ No. } & \multicolumn{2}{|c|}{ The Lost Boy } \\
\cline { 2 - 3 } & \multicolumn{1}{|c|}{ Asylum } & \multicolumn{1}{|c|}{ Chapter, Page, Paragraph } \\
\hline 1. & The garage & Ch.1, P.7, Par.3 \\
\hline 2. & County hospital & Ch.2, P.28, Par.1 \\
\hline 3. & Foster home & Ch.2, P.29, Par.4 \\
\hline 4. & Psychiatrist's room & $\begin{array}{l}\text { Ch.5, P.75 } \\
\text {-76, Par.11 }\end{array}$ \\
\hline 5. & The "Dog House" & Ch.5, P.87, Par.1 \\
\hline 6. & Hillcrest & Ch.7, P.116, Par.3 \\
\hline 7. & Detainee section & Ch.7, P.117, Par.1 \\
\hline 8. & Livingroom couch & Ch.8, P.137, Par.4 \\
\hline
\end{tabular}


Table 2. Asylum in The Lost Boy

\begin{tabular}{|c|c|c|}
\hline \multirow{2}{*}{ No. } & \multicolumn{2}{|c|}{ A Man Named Dave } \\
\hline & Asylum & Chapter, Page, Paragraph \\
\hline 1. & The garage & Ch.1, P.7, Par.1 \\
\hline 2. & The nurse's office & Ch.1, P.24, Par.6 \\
\hline
\end{tabular}

Table 3. Asylum in A Man Named Dave

In the table above, the most often appeared asylum was in The Lost Boy, the second was $A$ Child Called It and the third was A Man Named Dave. As in the elite table, asylum appeared most often in the second novel because in this novel David moved from one foster home to another and here he met many people, that was why he experienced asylum most in his second novel.

\subsubsection{Punishment in A Child Called It, The Lost Boy, and A Man Named Dave Trilogy}

This section described the action of punishment in A Child Called It, The Lost Boy, and A Man Named Dave trilogy. The explanations can be seen in the table below.

\begin{tabular}{|c|c|c|}
\hline \multirow{2}{*}{ No. } & \multicolumn{2}{|c|}{ A Child Called It } \\
\hline & Punishment & Chapter, Page, Paragraph \\
\hline 1. & Given no food & Ch.1, P.7, Par.2 \\
\hline 2. & $\begin{array}{l}\text { Smashed by } \\
\text { David's mother }\end{array}$ & $\begin{array}{l}\text { Ch.3, P.21 } \\
-22 \text {, Par.4 }\end{array}$ \\
\hline 3. & $\begin{array}{l}\text { Kicked by David's } \\
\text { mother }\end{array}$ & Ch.3, P.26, Par.1 \\
\hline 4. & $\begin{array}{l}\text { Burned by David's } \\
\text { mother }\end{array}$ & Ch.3, P.28, Par.2 \\
\hline 5. & $\begin{array}{l}\text { Smacked by } \\
\text { David's mother }\end{array}$ & Ch.3, P.22, Par.2 \\
\hline 6. & $\begin{array}{l}\text { Punched by } \\
\text { David's mother }\end{array}$ & Ch.3, P.24, Par.1 \\
\hline 7. & $\begin{array}{l}\text { Banned from } \\
\text { watching TV } \\
\text { forever }\end{array}$ & Ch.3, P.25, Par.1 \\
\hline 8. & Swallowed soap & Ch.3, P.26, Par.1 \\
\hline 9. & $\begin{array}{l}\text { Finish all chores in } \\
\text { his house }\end{array}$ & Ch.3, P.26, Par.2 \\
\hline 10. & $\begin{array}{l}\text { His mother only } \\
\text { called him "The } \\
\text { Boy" }\end{array}$ & Ch.4, P.31, Par.4 \\
\hline 11. & $\begin{array}{l}\text { He was not } \\
\text { allowed to go with } \\
\text { his family to } \\
\text { superslide }\end{array}$ & Ch.4, P.34, Par.2 \\
\hline 12. & $\begin{array}{l}\text { Swallowed } \\
\text { ammonia }\end{array}$ & Ch.4, P.46, Par.4 \\
\hline 13. & $\begin{array}{l}\text { Nose bleed and } \\
\text { missed a tooth }\end{array}$ & Ch.4, P.33, Par.2 \\
\hline 14. & $\begin{array}{l}\text { Slapped by } \\
\text { David's mother }\end{array}$ & Ch.5, P.50, Par.2 \\
\hline 15. & $\begin{array}{l}\text { Whipped with } \\
\text { dog's chain by } \\
\text { David's mother }\end{array}$ & Ch.6, P.69, Par.1 \\
\hline 16. & David was & Ch.6, P.63, Par.3 \\
\hline
\end{tabular}

98 | Jurnal Kredo

Vol. 3 No. 1 Oktober 2019

\begin{tabular}{|c|l|l|}
\hline & $\begin{array}{l}\text { confined in a room } \\
\text { filled with } \\
\text { ammonia and } \\
\text { Clorox }\end{array}$ & \\
\hline 17. & $\begin{array}{l}\text { David had to skate } \\
\text { outside during the } \\
\text { chilly weather }\end{array}$ & Ch.6, P.71, Par.2 \\
\hline
\end{tabular}

Table 1. The Action of Punishment in $A$ Child Called It

\begin{tabular}{|c|l|l|}
\hline \multirow{2}{*}{ No. } & \multicolumn{2}{|c|}{ The Lost Boy } \\
\cline { 2 - 3 } & \multicolumn{1}{|c|}{ Punishment } & Chapter, Page, Paragraph \\
\hline 1. & $\begin{array}{l}\text { Slapped by } \\
\text { David's mother }\end{array}$ & Ch.1, P.9, Par.5 \\
\hline 2. & $\begin{array}{l}\text { Yanked by } \\
\text { David's mother }\end{array}$ & Ch.1, P.10, Par.4 \\
\hline 3. & $\begin{array}{l}\text { Grounded by } \\
\text { Lilian }\end{array}$ & Ch.5, P.88, Par.8 \\
\hline 4. & Punched by John & Ch.6, P.106, Par.1 \\
\hline 5. & $\begin{array}{l}\text { David had to } \\
\text { moved to Hillcrest }\end{array}$ & Ch.6, P.115, Par.7 \\
\hline 6. & $\begin{array}{l}\text { Mr Tapley gave } \\
\text { David a lot of } \\
\text { homework }\end{array}$ & Ch.10, P.176, Par.5 \\
\hline
\end{tabular}

Table 2. The Action of Punishment in The Lost Boy

\begin{tabular}{|c|c|c|}
\hline \multirow{2}{*}{ No. } & \multicolumn{2}{|c|}{ A Man Named Dave } \\
\hline & Punishment & Chapter, Page, Paragraph \\
\hline 1. & $\begin{array}{l}\text { David had to sleep } \\
\text { on a shabby cot } \\
\text { without a blanket }\end{array}$ & Ch.1, P.7, Par.2 \\
\hline 2. & $\begin{array}{l}\text { Pulled out by } \\
\text { David's mother }\end{array}$ & Ch.1, P.8, Par.4 \\
\hline 3. & $\begin{array}{l}\text { David's mother } \\
\text { only called him } \\
\text { from "The Boy" to } \\
\text { "It" }\end{array}$ & Ch.1, P.9, Par.1 \\
\hline 4. & Given no food & Ch.1, P.9, Par.1 \\
\hline 5. & $\begin{array}{l}\text { Beaten by David's } \\
\text { mother }\end{array}$ & Ch.1, P.13, Par.2 \\
\hline 6. & $\begin{array}{l}\text { Strangled by } \\
\text { David's mother }\end{array}$ & Ch.1, P.16, Par.5 \\
\hline 7. & $\begin{array}{l}\text { Strangled by } \\
\text { David's mother }\end{array}$ & Ch.1, P.19, Par.3 \\
\hline 8. & $\begin{array}{l}\text { David was isolated } \\
\text { from his airmen } \\
\text { fellow in squadron }\end{array}$ & Ch.3, P.48, Par.3 \\
\hline
\end{tabular}

Table 3. The Action of Punishment in $A$

Man Named Dave

As can be seen from the table above, David received the most punishment in his first novel titled A Child Called It. In the second and third novel, David received punishment not as many as in the first novel because David most often met his mother in A Child Called. His mother was the one who gave him the most punishment because he was considered as a bad boy by her. 
3.2. The Effects of Madness in David's Character Through Himself in $A$ Child Called It, The Lost Boy, and A Man Named Dave Trilogy

There were some effects of madness in David's character through himself in $A$ Child Called It, The Lost Boy, and A Man Named Dave trilogy. In this part, the researcher explained the effects of madness in David's character through the trilogy from the first until the third book.

\subsubsection{The Effects of Madness in David's Character Through Himself in $A$ Child Called It}

In the first novel, A Child Called It, the researcher found that there were some effects of madness in David's character through himself which can be seen from the paragraph below.

"When Mother decided that the "corner treatment" was no longer effective, I graduated to the "mirror treatment". In the beginning, it was a no notice form of punishment. Mother would simply grab me and smash my face against the mirror, smearing my tearstreaked face on the slick, reflective glass. Then she would order me to say over and over again. "I'm a bad boy! I'm a bad boy! I'm a bad boy!' I was then forced to stand, staring into the mirror. I would stand there with my hands locked to my sides, weaving back and forth, dreading the moment when the second set of television commercials aired." (A Child Called It, p.21-22)

He was considered as a bad boy and must accept a punishment from his mother, which was the "mirror treatment", got smashed on his face againts the mirror, and he had to say he was a bad boy. Those punishments above could be considered as physical and mental harassment. From the paragraph above, it can be seen that he received physical and mental punishment by his mother.

\subsubsection{The Effects of Madness in David's Character Through Himself in The Lost Boy}

After knowing the effects of madness in David's character through himself in A Child Called It, the researcher also described the effects of madness in David's character through himself in The lost boy, which was the second novel. For years, David had to follow his mother's game and punishments, because he was a bad boy, as stated by his mother repeatedly in the novel.

"“I'm sorry, " I stuttered in a low voice. I was still unsure of Aunt Mary's intentions. I retreated into my protective position. "I was a bad boy, and I deserved what I got!" "'.(The Lost Boy, p.31)

Regarding punishment, Foucault also said that mad and deviant people were made to have feelings of guilt. From the paragraph above, he admitted that he was a bad boy and felt that what he has been experiencing he should have gotten. Guilt is a kind of mental punishment.

"Sometimes during my free period, I'd stroll over to visit my English teacher, Mr Tapley. Since he didn't have class that period, $\mathrm{Mr}$ Tapley used his time to correct papers. I'd plant my elbows on his desk and bug him with an endless stream of questions about my future. He knew how hard I struggled, but I was too embarrassed to tell him why I would always fall asleep. Mr Tapley would look up from his pile of work, run a hand through his thinning hair and feed me just enough advice to get me through the weekend - to bury myself in my homework. "(The Lost Boy, p.171)

David was punished by his teacher, Mr. Tapley by giving David myriad homework. He was punished because he often overslept in class. The type of punishment Mr Tapley gave to David was physical punishment because he had to complete the homework.

\subsubsection{The Effects of Madness in David's Character Through Himself in $A$ Man Named Dave}

The researcher found some effects of madness in David's character through himself in the last novel of him titled $A$ Man Named Dave. The researcher explained the effects by taking some paragraphs from the novel A Man Named Dave.

"I warn myself to stay focused. I know she plans on using the broom as a weapon, either against my chest or face. Sometimes when we're alone, Mother likes to smash the end of 
the broom directly behind my knees. If she has me follow her into the kitchen, I'm dead. I won't be able to walk to school, let alone run. But if Mother keeps me on the stairs, I know she'll only hit me in my upper body. "(A Man Named Dave, p.13)

From the paragraph above, it was said that David was also often beaten by his mother by using a broom in the chest, knees or his upper body. When his mother hitted him on the knee, he could not walk to school. It was clear that his mother gave physical punishment to him.

"“Make certain it doesn't, airman. Damn sure! Understand this," the master sergeant said as he shot up from his chair and stood inches in front of my nose, "the United States Air Force has no room whatsoever for whiny little momma's boys. Our sole objective, our sole purpose, is to protect the freedom of this nation's democracy. Is that clear? If you can't handle the magnitude of that responsibility, then get out! If you continue on your present course, I will have no alternative but to have you undergo psychiatric evaluation for possible medical discharge. Do I make myself clear ... Airman Pelzer?"”(A Man Named Dave, p.47)

David's airmen fellow found David delirious while sleeping calling his mother for several times and because of that he had to be called by his master sergeant. He was considered as a spoiled child who missed his mother. This was kind of mental punishment because the figure of an airman must be mature, firm and not weak. Here, he must be fully assertive and independent rather than to be homesick of his mother like a kid because he was not a kid anymore. He was a adult male. He was considered to think more about the country than his mother when he decided to enter the US Airforce. If he continued, he would be taken to a psychiatrist.

The researcher concluded that David received punishments, both mental and physical punishments in the trilogy as the effects of madness he had faced. Both types of punishment appeared in all three novels repeatedly.

\section{CONLUSION}

There are some conclusions of this study based on the findings on the previous explanation. First, the researcher concluded that there were three indicators of madness experienced by David through A Child Called It, The Lost Boy, and A Man Named Dave trilogy. They were the elite, asylum, and punishment. The three madness indicators that experienced by David in each novel had different frequencies and percentages in each novel. Second, the researcher also found that there were two types of punishment in the trilogy. They were the mental and physical punishments. Both physical and mental punishments were the punishments that David received in A Child Called It, The Lost Boy, and A Man Named Dave trilogy. David got the punishments because he was considered mad and deviant by the elite.

Throughout the trilogy, because of his mad behavior (such as stole food, burned his classroom and often fell asleep during class time), he often had to suffer in his life. The people around David in $A$ Child Called It, The Lost Boy, and A Man Named Dave trilogy were mostly the elite.

\section{REFERENCES}

Foucault, M. 1965. Madness and civilization: A history of insanity in the age of reason. New York: Pantheon Books.

Foucault, M. 2002. The archaeology of knowledge, menggugat sejarah ide. Yogyakarta: IRCiSoD.

Jatman, D. 1985. Sastra, psikologi, dan masyarakat. Bandung: Penerbit Alumni.

Martono, N. 2014. Sosiologi pendidikan Michel Foucault: Pengetahuan, kekuasaan, disiplin, hukuman, dan seksualitas. Jakarta: Raja Grafindo Persada.

Nazir, Mohammad. 1988. Metode Penelitian. Jakarta: Ghalia Indonesia.

Pelzer, D. 1995. A child called it. California: Daly City.

100 | Jurnal Kredo

Vol. 3 No. 1 Oktober 2019 
Pelzer, D. 1997. The lost boy. California: Daly City.

Pelzer, D. 1999. A man named Dave. California: Daly City.

Rosidi, N. 2013. Kegilaan menurut Michel Foucault. Retrieved from http://kompasiana.com/amp/nanangrosidi/kegilaan-menurut-michel-

foucault_552002f88133113d209dfd85. 